\title{
Functional and genetic characterization of mcpC, which encodes a third methyl-accepting chemotaxis protein in Bacillus subtilis
}

\author{
Jakob Müller, ${ }^{1}$ Stacey Schiel, ${ }^{2}$ George W. Ordal ${ }^{2}$ and Hans H. Saxild ${ }^{1}$ \\ Author for correspondence: Hans H. Saxild. Tel: +4545252495 . Fax: +4545882660 . \\ e-mail: hhs@im.dtu.dk
}

\footnotetext{
1 Department of Microbiology, Technical University of Denmark, Bldg 301, DK-2800 Lyngby, Denmark

2 Department of Biochemistry, University of Illinois, 190 Medical Sciences Bldg, 506

S. Mathews Ave, Urbana, IL 61801-3618, USA
}

\begin{abstract}
A 3135 bp DNA segment downstream of the spl gene on the Bacillus subtilis chromosome was cloned and its nucleotide sequence determined. An open reading frame capable of encoding a putative protein of 654 amino acids with a calculated molecular mass of $72 \cdot 1 \mathrm{kDa}$ was identified. The deduced amino acid sequence was similar to the McpA and McpB proteins of B. subtilis. McpA and McpB encode different methyl-accepting chemotaxis proteins (MCPs). A mutant strain containing an antibiotic resistance DNA cassette inserted into the region containing the MCP-like reading frame suffered a complete loss of taxis to the amino acids cysteine, proline, threonine, glycine, serine, lysine, valine and arginine. The open reading frame was designated mcpC. The wildtype and an mcpC mutant strain were analysed for their content of methylated proteins and it was found that mcpC encodes a methylated membrane protein that has previously been designated H3. These results show that mcpC encodes a third MCP in B. subtilis. The transcription start site upstream of the mcpC gene was determined by primer extension analysis and it was found to be preceded by a potential promoter sequence that is recognized by the $\sigma^{D}$ form of RNA polymerase. The level of $\beta$-galactosidase expressed from a transcriptional mcpC-lacZ fusion was increased threefold when cells entered the stationary phase. No $\beta$-galactosidase could be detected in a sigD genetic background.
\end{abstract}

Keywords : chemotaxis receptor protein, methylation, $m c p C$ gene sequence, $m c p C$ expression, $\sigma^{\mathrm{D}}$-dependent expression

\section{INTRODUCTION}

Chemotaxis is a primitive behavioural system by which bacteria travel towards better environments as the result of modulating tendency to swim smoothly [anticlockwise $(\mathrm{ACW})$ rotation of flagella] or tumble [clockwise (CW) rotation of flagella]. Rotational direction is governed by the operation of a two-component system, involving an autophosphorylating kinase, CheA, and a response regulator, CheY (Bischoff \& Ordal, 1991; Fuhrer \& Ordal, 1991). When Bacillus subtilis encounters increasing attractant concentration, more attractant will bind to the receptors (methyl-accepting chemotaxis

Abbreviation: MCP, methyl-accepting chemotaxis protein.

The EMBL accession number for the nucleotide sequence reported in this paper is $X 97385$. proteins; MCPs) to activate CheA and produce more CheY-P, which will bind to switches at the base of the flagella to cause ACW rotation (excitation). When the bacteria head, by chance, towards lower attractant concentrations, attractant leaves the receptors and $\mathrm{CW}$ rotation ensues. Adaptation, to return the ratio of $\mathrm{ACW} / \mathrm{CW}$ rotation to normal (random) even with the stimulus still present, occurs with release of methanol from methylesterified receptors. This involves the methylesterase CheB, which is also phosphorylated by CheA-P, and thereby activated (Kirsch et al., 1993a). The methyltransferase CheR, using $S$-adenosyl-methionine, puts methyl groups onto the receptors (Kirsch et $a l ., 1993 \mathrm{~b})$. At least two other proteins, not found in the Gram-negative Escherichia coli, participate in the reactions of excitation and adaptation - CheC and CheD and they are also thought to interact with the receptors (Rosario \& Ordal, 1996). Finally, B. subtilis has two 
other proteins which may help couple signals from the receptors to CheA - CheW and $\mathrm{CheV}$ (Hanlon et al., 1992; Rosario et al., 1994). Thus, a number of proteins - CheA, CheB, CheR, CheC, CheD, CheW and CheV apparently bind to the receptors and might be expected to cause sequence conservation among the receptors to maintain functional protein-protein interactions.

The receptors themselves are methylesterified on selected glutamate side chains. Most of the receptors from a variety of organisms have a similar three-dimensional geometry - an N-terminal region between two membrane-spanning regions, where interactions with attractants or repellents are thought to occur, and a C-terminal region where interactions with the chemotaxis proteins mediating sensory transduction are thought to occur (Le Moual \& Koshland, 1996). Thus, all receptors known contain a region where $\mathrm{CheW}$ and CheA are thought to interact. In B. subtilis, two MCPs, McpA and McpB, have been identified. McpA mediates taxis to glucose and $\alpha$-methyl glucosides and McpB mediates all taxis to asparagine, but only some taxis to aspartate, histidine and glutamine (Hanlon \& Ordal, 1994). In the four gene cluster containing $m c p A$ and $m c p B$, two other genes, $\operatorname{tl} p A$ and $\operatorname{tl} p B$, are located. They encode proteins with extensive homology to both McpA and $\mathrm{McpB}$ but their function is unknown. A third transducer-like protein, TlpC, encoded by a gene not coupled to the $m c p A$ gene cluster only shows similarity to McpA and McpB in the C-terminal region. TlpC mutants have normal chemotaxis phenotype (Hanlon et al., 1994). One feature that has proven unique among four of the receptors of $B$. subtilis thus far studied McpA, McpB, TlpA and TlpB - is extensive amino acid sequence conservation in the $\mathrm{N}$-terminal part. This is believed to reflect interactions with binding proteins, perhaps similar to the maltose-binding proteins of $E$. coli (and also the galactose- and ribose-binding proteins of E. coli; Kossmann et al., 1988), which bind their respective ligands and then bind to the methylated receptors.

In this report, we describe the identification of a new MCP in B. subtilis that is encoded by the gene $m c p C$. It is demonstrated that $\mathrm{McpC}$ is involved in chemotaxis and that $m c p C$ expression is dependent on the sigD gene product.

\section{METHODS}

Bacterial strains, plasmids and media. The bacterial strains and plasmids used in this work are listed in Table 1. B. subtilis was grown in Spizizen minimal salt medium (Saxild $\&$ Nygaard, 1987) supplemented with $1 \mu \mathrm{g}$ thiamin hydrochloride $\mathrm{ml}^{-1}, 50 \mu \mathrm{g}$ L-tryptophan $\mathrm{ml}^{-1}$ and with $0.4 \%$ of the stated carbon source. Additional amino acids required by auxotrophic strains were added at $50 \mu \mathrm{g} \mathrm{ml}^{-1}$ concentrations. L broth (Difco) was used as a rich medium for both E. coli and B. subtilis. Culturing of cells was performed at $37^{\circ} \mathrm{C}$. For selection of antibiotic resistance the following concentrations were used: ampicillin, $100 \mu \mathrm{g} \mathrm{m}^{-1}$; chloramphenicol, $5 \mu \mathrm{g}$ $\mathrm{ml}^{-1}$; neomycin, $5 \mu \mathrm{g} \mathrm{ml}^{-1}$; erythromycin, $150 \mu \mathrm{g} \mathrm{m}^{-1}(E$. coli); and erythromycin and lincomycin, 1 and $25 \mu \mathrm{g} \mathrm{ml}^{-1}$, respectively (B. subtilis).
DNA manipulations and genetic techniques. Chromosomal DNA from B. subtilis was isolated as described previously (Saxild \& Nygaard, 1987). Plasmid DNA was isolated by the alkaline/SDS method (Birnboim \& Doly, 1979). Transformation of E. coli (Hanahan, 1983) and B. subtilis (Boylan et al., 1972) was performed as described previously. Treatment of DNA with restriction enzymes, T4 DNA ligase and the Klenow fragment of DNA polymerase was performed as recommended by the supplier (Gibco-BRL). For Southern blot analysis, DNA was blotted onto a nitrocellulose membrane (GeneScreenTM; NEN Research Products). The DIG DNA Labelling and Detection kit (Boehringer Mannheim) was used for colorimetric detection of the hybridization products. The recipe supplied by the manufacturer was followed.

DNA sequencing. DNA sequences were obtained by the chaintermination reaction method with dideoxyribonucleotides as described by Sanger et al. (1977). All sequencing analysis was done on the double-stranded plasmid DNA templates pCW10 and pBOEC335.

Isolation of RNA and primer extension analysis. Total RNA from $B$. subtilis was isolated using a previously described method (Saxild et al., 1995). The primer extension analysis using SuperScript $\mathrm{RNaseH}^{-}$reverse transcriptase (Gibco-BRL) has also been described previously by Saxild et al. (1995). The radiolabelled cDNA products were separated on a $6 \%(\mathrm{w} / \mathrm{v})$ polyacrylamide sequencing gel and visualized by autoradiography.

In vivo methylation assay and PAGE. The strains OI1085, OI3202, OI3280 and OI3282 were grown to 180 Klett units in $\mathrm{L}$ broth with antibiotic where appropriate and washed three times in chemotaxis buffer (Ordal \& Goldman, 1975) containing chloramphenicol $\left(250 \mu \mathrm{g} \mathrm{ml}^{-1}\right)$. The cells were then resuspended in protoplast buffer (Ullah \& Ordal, 1981) containing $250 \mu \mathrm{g}$ chloramphenicol ml $\mathrm{ml}^{-1}$ at an $\mathrm{OD}_{600}$ of $1 \cdot 0$ (Pharmacia-LKB Ultrospec III spectrophotometer). Lysozyme was added to a final concentration of $1 \mathrm{mg} \mathrm{m}^{-1}$, and the cells were incubated at $37^{\circ} \mathrm{C}$ with gentle shaking for $20 \mathrm{~min}$. Methylation was initiated by the addition of $50 \mu \mathrm{Ci}$ [methyl$\left.{ }^{3} \mathrm{H}\right]$ methionine $\mathrm{ml}^{-1}\left(1.85 \times 10^{6} \mathrm{~Bq} \mathrm{ml}^{-1}\right)\left(6.0 \times 10^{-7} \mathrm{M}\right)$. Incubation was continued for an additional $15 \mathrm{~min}$ and samples were frozen in a dry ice/acetone bath. Protoplasts were recovered by centrifugation at $4^{\circ} \mathrm{C}$ and resuspended in $100 \mu \mathrm{l}$ $2 \times$ SDS/EDTA solubilizer buffer (Hanlon \& Ordal, 1994). SDS-PAGE was performed by the method of Laemmli (1970). Samples were solubilized in $2 \times$ SDS/EDTA solubilizer buffer by boiling for $7 \mathrm{~min}$ and applied to $10 \%$ SDS-PAGE gels and run at $25 \mathrm{~mA}$ for $3 \mathrm{~h}$. The labelled proteins were then visualized by fluorography by the method of Laskey \& Mills (1975).

Capillary assay. Strains were streaked out on TBAB (Difco) plates (with antibiotic where appropriate) and grown overnight at $30^{\circ} \mathrm{C}$. Single colonies were resuspended in $2 \mathrm{ml} \mathrm{TBR}$ $(1 \%, \mathrm{w} / \mathrm{v}$, Bactotryptone; $0.5 \% \mathrm{NaCl})$ and diluted $1: 50$ in minimal medium containing glycerol as the carbon source $(20 \mathrm{mM})$. Cultures were grown for $4 \mathrm{~h}$ and washed in chemotaxis buffer. Cells were finally resuspended in chemotaxis buffer to an $\mathrm{OD}_{600}$ of 0.001 and tested for taxis to all 20 amino acids. Capillary assays were performed as previously described (Ordal et al., 1977).

$\beta$-Galactosidase assay. Cells for enzyme measurement were harvested in mid-exponential growth phase or in early stationary phase and homogenized by sonication in $30 \mathrm{mM}$ phosphate buffer (pH 7.5), 1 mM EDTA and 1 mM DTT. Cell debris was removed by centrifugation. $\beta$-Galactosidase was measured according to the method of Miller (1972). All the 
Table 1. Bacterial strains and plasmids

\begin{tabular}{|c|c|c|}
\hline Strain/plasmid & Characteristics & Source/reference \\
\hline \multicolumn{3}{|l|}{ B. subtilis } \\
\hline $\mathrm{HH} 1$ & $\operatorname{trp} C 2$ & $\begin{array}{l}\text { 168; C. Anagnostopoulos, INRA, } \\
\text { Jouy-en-Josas, France }\end{array}$ \\
\hline HH71 & $\operatorname{trpC2}$ purL8 prg-71::lacZ (cat) & Saxild et al. (1994) \\
\hline HH226 & $\operatorname{trp} C 2$ amyE::mcpC-lacZ; $\mathrm{Neo}^{\mathrm{R}}$ & $\begin{array}{l}\text { Transformation of } \mathrm{HH} 1 \text { by } \mathrm{pHH} 1008 \\
\text { digested with } \mathrm{XhoI}\end{array}$ \\
\hline $\mathrm{HH} 247$ & $\operatorname{trpC2}$ sigD::pLM5 (cat) & $\begin{array}{l}\text { 1A716; Bacillus Genetic Stock Center, } \\
\text { Columbus, OH, USA }\end{array}$ \\
\hline JM6 & $\operatorname{trp} \mathrm{C} 2 m c p C:: \mathrm{pBOEA} 335(c a t) ; \mathrm{Cm}^{\mathrm{R}}$ & Transformation of $\mathrm{HH} 1$ by pBOEA335 \\
\hline JM9 & $\operatorname{trp} C 2 \operatorname{mcp} C:: \mathrm{erm}$ & $\begin{array}{l}\text { Transformation of } \mathrm{HH} 1 \text { by } \\
\text { pBOEB }(e r m) 335 \text { selecting } \mathrm{Er}^{\mathrm{R}} \\
\text { transformants screened for } \mathrm{Cm}^{\mathrm{s}}\end{array}$ \\
\hline JM10 & $\operatorname{trpC2}$ mcpC::erm sigD::pLM5 (cat); $\mathrm{Cm}^{\mathbf{R}}$ & $\begin{array}{l}\text { Transformation of JM9 by DNA from } \\
\text { HH } 247\end{array}$ \\
\hline OI1085 & $\operatorname{trpF7}$ bisH2 metC & Ordal \& Goldman (1975) \\
\hline OI3202 & $\operatorname{trpF7}$ his $H 2$ metC $\Delta(m c p B-t l p A-m c p A-t l p B) \Delta t l p C$ & G. W. Ordal \\
\hline OI3280 & trpF7 bisH2 metC mcpC::erm; Er ${ }^{\mathrm{R}}$ & $\begin{array}{l}\text { Transformation of OI1085 by DNA } \\
\text { from JM9 }\end{array}$ \\
\hline OI3281 & $\operatorname{trpF7}$ his $H 2$ metC $\Delta(m c p B-t l p A-m c p A-t l p B) \Delta t l p C m c p C:: e r m ; \mathrm{Er}^{\mathbf{R}}$ & $\begin{array}{l}\text { Transformation of OI3202 by DNA } \\
\text { from JM9 }\end{array}$ \\
\hline \multicolumn{3}{|l|}{ E. coli } \\
\hline MC1061 & $\begin{array}{l}\mathrm{F}^{-} \text {araD139 } \Delta(\text { ara-leu }) 7696 \text { galE15 galK16 } \Delta(\text { lac }) X 74 \text { rpsL }\left(\mathrm{Str}^{\mathrm{R}}\right) \text { bsdR2 } \\
\left(\mathrm{r}^{-} \mathrm{m}^{-}\right) \operatorname{mcr} A \mathrm{mcrB}\end{array}$ & Stratagene \\
\hline \multicolumn{3}{|c|}{ 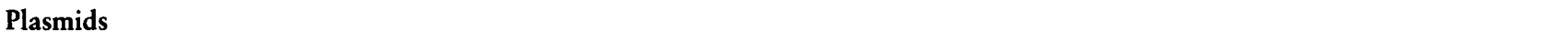 } \\
\hline $\mathrm{pKS}(+)$ & $A p^{R}$ & Stratagene \\
\hline pDG268neo & $\begin{array}{c}\operatorname{Ap}^{\mathrm{R}} \text { (E. coli), Neo }{ }^{\mathrm{R}} \text { (B. subtilis); vector used for integration of } \\
\text { transcriptional lacZ fusions into the amyE gene of B. subtilis }\end{array}$ & Saxild et al. (1995) \\
\hline pBOE335 & $\begin{array}{l}\mathrm{Ap}^{\mathrm{R}}(E . \text { coli }), \mathrm{Cm}^{\mathrm{R}} \text { (B. subtilis); pUC19 containing the cat gene cloned } \\
\text { into the KasI site }\end{array}$ & Saxild et al. (1996) \\
\hline pHH1008 & $\begin{array}{l}0.8 \mathrm{~kb} \text { HindIII fragment from pCW10 ligated to pGD268neo digested } \\
\text { with HindIII; used for integration of a transcriptional fusion of } m c p C \\
\text { to lacZ into the } a m y E \text { gene }\end{array}$ & This work \\
\hline pHH1017 & $\begin{array}{l}\operatorname{Ap}^{\mathrm{R}}(E . \text { coli }), \operatorname{Er}^{\mathrm{R}}(E . \text { coli and B. subtilis }) ; 1 \cdot 1 \mathrm{~kb} \text { EcoRI fragment } \\
\text { containing the erm gene ligated to } \mathrm{pKS}(+) \text { digested with EcoRI }\end{array}$ & Saxild et al. (1996) \\
\hline $\mathrm{pCW} 1$ & $\begin{array}{l}\text { pSGMU38 derivative (Saxild et al., 1994) containing } 2.5 \mathrm{~kb} \text { B. subtilis } \\
\text { DNA rescued from chromosomal DNA from strain } \mathrm{HH} 71\end{array}$ & This work \\
\hline $\mathrm{pCW} 10$ & $\begin{array}{l}2.5 \mathrm{~kb} S p h \mathrm{I}-E c o \mathrm{RI} \mathrm{DNA} \text { fragment from } \mathrm{pCW} 1 \text { ligated to } \mathrm{pKS}(+) \text { that } \\
\text { has been digested with EcoRV and EcoRI; the SphI site of the insert } \\
\text { was blunt-ended with Klenow DNA polymerase prior to ligation }\end{array}$ & This work \\
\hline pBOEA335 & $\begin{array}{l}1.2 \mathrm{~kb} \text { HindIII fragment from pCW } 10 \text { containing an internal part of } \\
m c p C \text { ligated to pBOE335 digested with HindIII; the direction of } \\
\text { transcription of the } m c p C \text { segment is in parallel with that of the lacZ } \\
\alpha \text { fragment of pBOE335 }\end{array}$ & This work \\
\hline pBOEB335 & $\begin{array}{l}1.2 \mathrm{~kb} \text { HindIII fragment from pCW10 containing an internal part of } \\
m c p C \text { ligated to pBOE335 digested with HindIII; the direction of } \\
\text { transcription of the } m c p C \text { segment is opposite of that of the lacZ } \alpha \\
\text { fragment of pBOE335 }\end{array}$ & This work \\
\hline $\mathrm{pBOEB}(\mathrm{erm}) 335$ & $\begin{array}{l}1 \cdot 1 \mathrm{~kb} \text { Smal-EcoRV fragment from pHH1017 containing the erm gene } \\
\text { cloned into the unique EcoRV site in the } 1.2 \mathrm{~kb} \text { HindII } m c p C \text { insert } \\
\text { in pBOEB335 }\end{array}$ & This work \\
\hline pBOEC 335 & $\begin{array}{l}\text { pBOE335 derivative containing a } 2 \cdot 0 \mathrm{~kb} \text { HindIII-BglII fragment rescued } \\
\text { from chromosomal DNA from strain JM6 }\end{array}$ & This work \\
\hline
\end{tabular}




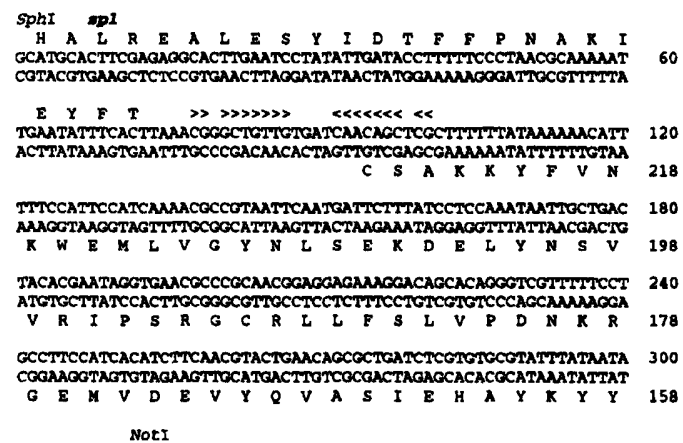

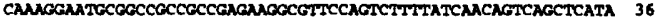

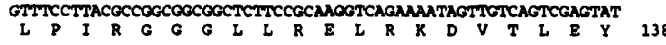

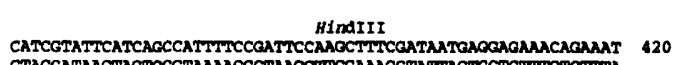

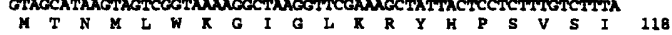

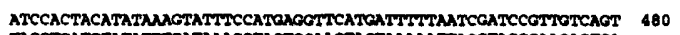

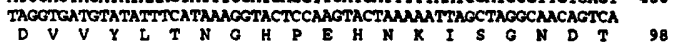
TGCTTGTOCCCATGTATGATCAGGAGMATCAOGCTCAMATTGTACMATMGAOCAGTCAT 540

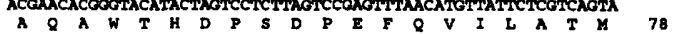

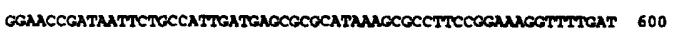
CCTTGGCTATTAAGACGGTAACTACTCOCGCGTATTTCGCOGMACGCCTTTCCAAMATA

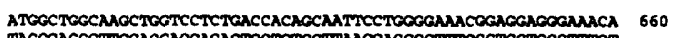

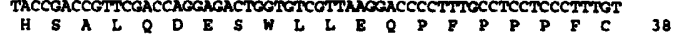
TTCTTCTTGMAGAONUTCACCCTCTCGATGTCACTCTCAGTGTACTTTCTMATEGTCAG 720

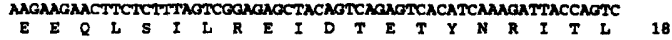

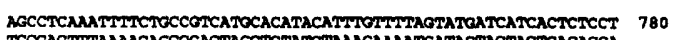

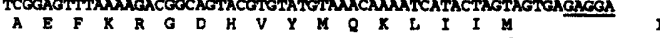
ares

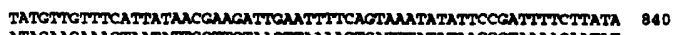

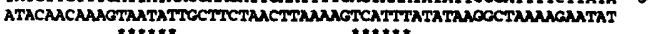

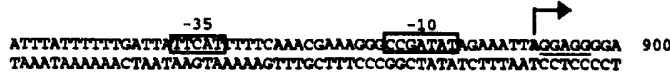

$\operatorname{mope}_{\mathrm{F}}$

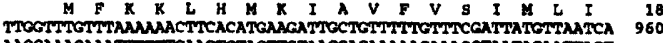
$\begin{array}{lllllllllllllllllllll}I & T & V & V & L & \text { L } & \text { M } & \text { L } & S & S & \mathbf{Y} & \text { L } & \text { T } & \text { L } & \text { X } & \text { P } & \text { M } & \text { I } & \text { T } & \text { E } & 38\end{array}$

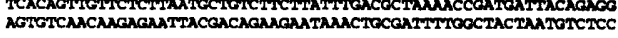

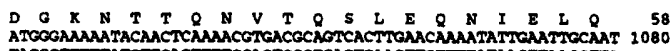
ATGCGAMAMATACAMCTCANACGTGACGCAOTCACTTGAACMAATATITANATTGCAAT 2080

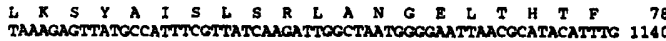
ATTTCTCAATACGOTANACCAATAGTTETAACCGATACCCCTTAATTGCGTATGTAAAC

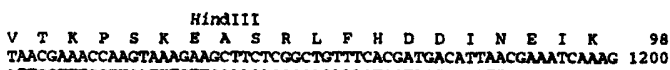
TAACGAAACAAGTAMAGAACCTTCTCGGCTGTTTCACGATGACATTAACGMATCANAC 1200

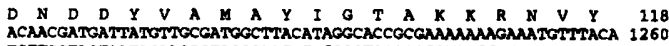
TGTTGCTACTAATACAACGCTACCGAMTGTATCCGTGCCGCTITITTICTTTACAMATGT

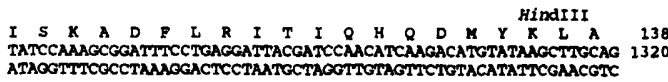

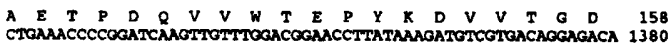
CTGAAACCCCOGATCAAOTTGTTTOGACOGACCTTIATAAAOATGTCGTGACACGAGACA 1380

$\begin{array}{llllllllllllllllllllll}M & I & V & T & A & S & X & A & I & L & D & R & 0 & K & V & I & G & V & A & S & 178\end{array}$ ACTAACMATGACGTAGCTTTCGCTAGAATCTGTCCGTTTTTTCACTATCCCCAACGGTCGA

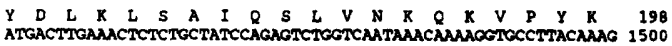
ATGACTTGAAACTCTCTGCTATCCAGAGTCTGGTCAATAAACAAAACGTCCCTTACAAAG 1500

G F A $F$ F L A A D A S G N I CTAAACGGAAAAATCGACTACGCTCGCCGTTAGAAAATCGGGTAGGCAGTTTTAGTTCCTT

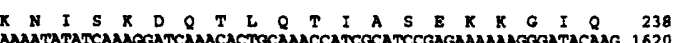
TMAM D V N O X Y V V Y O T I O E T O Y Y Y O G $\quad 258$ TACACTTACCCTHTTACCAACACATCOTTTECTAACCGCTCTETCCGACCTTCCACCCTT

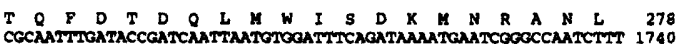

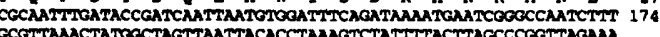
ECORV

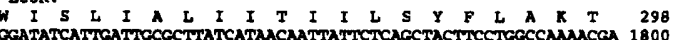

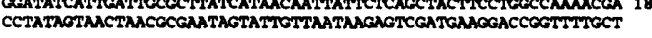

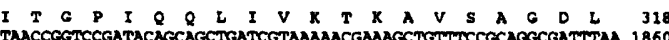
TAMCCCETCCGATACAGCAGCTGATCGTAMAAACGMAACTGTTTTCCCCAOGCGATTTAA 186 $\begin{array}{llllllllllllllllllll}T & V & R & A & E & S & X & S & X & D & E & V & G & I & L & T & R & D & F & N \\ C\end{array}$ OTCACGCGCGCCTTAGTTITAGATTCCTACTTCACCCATANATTGTTCTCTAMAGTTAG

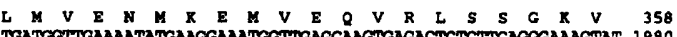

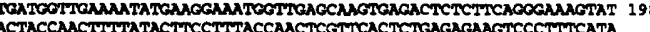

$\begin{array}{lllllllllllllllllllll}S & D & T & S & E & Q & L & T & A & V & A & A & E & T & N & E & R & S & O & Q & 378\end{array}$ CTEACACCTCTGMACNACTAACQOCTGTGCCTOCCQAMACTAMTGMAGAMGCGOACAAA 2040

I A $\quad$ K A I I E E V V A A G A S E E O A S E V E

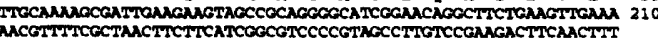
T I N F

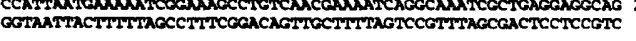

$\begin{array}{lllllllllllllllllllllll}G & G & I & K & E & R & S & K & S & S & E & D & A & S & Y & K & G & L & H & A & 438\end{array}$

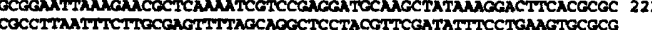

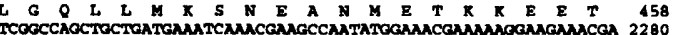

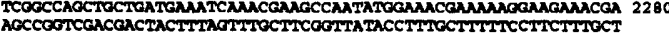

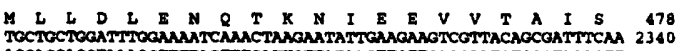
ACGACGACCTAAACCTITTANTTTGATTCTTATAACTTCTTCAGCMTTOTCGCTAAAGTT

A I S D R T N L L L A

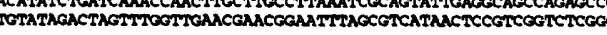

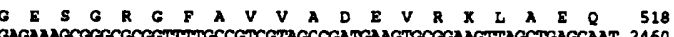

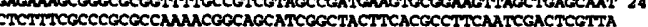

$S A$ L $S$ T $X$ H I $S$ E T HindIII

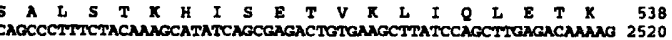

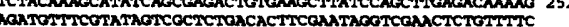

E A A S H A A M V V E A

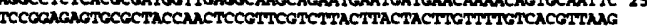

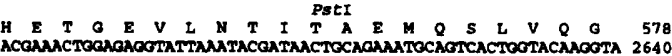

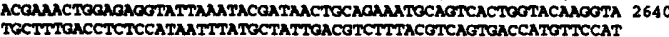
I D TRGATCACATHTACGCGGAAMTTCANAGAATGAGTCAACMACAGCTTTGCGATTTCTGAMG 2700

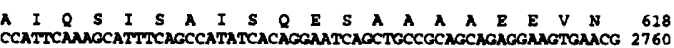

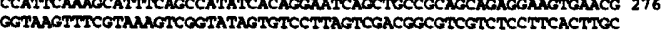

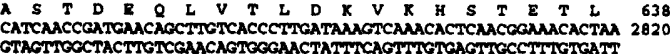

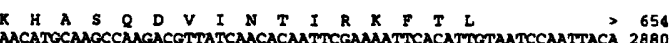
AACATGCAACCCAAGACGTTATCAACACAATTCGAAAMTCACAITTCTAATCCAAITACA >>>>>>>>>

TCCCCAMACATCATTTGTTTOCGGATTITTTATTTTATAAGATGAATAGATATGGTAGTC 2940 AGOCGTTTGTAGTMACAMCCCCTANAANATAMATATTCTACTTATCTATACCATCAC TAGANAMTGAMGGNAMAMGATAMATTTTAACTMAAATCTAMACGMACATCTOGOAOGA 3000

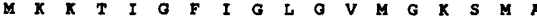
ATGACCTTGAAANAAACAATFGGTITTATCGGTCTTGGANTAATGCGAAAAACATGECA 3060 $S$ S H I L N CACATATTCTCAATGACGGCCATCCTGTATTGGTGTACACCCGCACAMAMGAUAAGCGA 3120 $\mathrm{R}$ H $T$ S $\mathrm{X}$ AAGCATACTTCANA 3135 TTCOTATGAATTTT

Fig. 1. Nucleotide sequence of a $3.1 \mathrm{~kb}$ region downstream of $\mathrm{spl}$ containing the mcpC and orf1 genes. The deduced amino acid sequences are shown above $(m c p C)$ or beneath (orf1) the nucleotide sequence. The -35 and -10 elements of the $\sigma^{\mathrm{D}}$-dependent promoter upstream of $\operatorname{mcpC}$ are boxed. The position of the transcription start site of the $m c p C$ gene is shown by a bent arrow. The -35 and -10 elements of a putative $\sigma^{A}$-dependent promoter upstream of orf 1 are indicated by asterisks beneath the sequence. Potential ribosome-binding sites in front of the reading frames are indicated by lines beneath the sequence. Potential factor-independent transcription terminator structures downstream of $s p /$ and $m c p C$ are indicated $(>>><<)$. Only relevant restriction sites are indicated. 
determinations were repeated at least three times. One unit of specific enzyme activity was defined as $1 \mathrm{nmol}$ substrate converted $\mathrm{min}^{-1}$ (mg protein $)^{-1}$. Total protein was determined by the Lowry method.

Cloning of the chromosomal region containing mcpC. DNA flanking the pSGMU38 insertion point in strain HH71 [prg71 : : lacZ (pSGMU38)] (Saxild et al., 1994) was isolated using the standard plasmid rescue technique (Youngman et al., 1984). DNA from strain HH71 was digested with SphI, ligated and subsequently transformed into E. coli strain MC1061 by selection for $\mathrm{Ap}^{\mathrm{R}}$. A plasmid (pCW1) containing a $2.5 \mathrm{~kb}$ insert of $B$. subtilis DNA was isolated from one of the transformants. pCW1 was digested with $S p h \mathrm{I}$, and the DNA was blunt-ended with the Klenow fragment of DNA polymerase and subsequently cleaved with EcoRI. EcoRI cuts the plasmid in the sequence containing the spollAA RBS that has been inserted in front of the lacZ gene of pSGMU38 (Errington, 1986). The $2.5 \mathrm{~kb}$ fragment was isolated from an agarose gel and ligated to EcoRV- and EcoRI-cleaved pBluescript. The ligation mixture was transformed into MC1061 by selection for $\mathrm{Ap}^{\mathrm{R}}$. A plasmid containing the $2.5 \mathrm{~kb}$ insert was named pCW10. pCW10 was digested with HindIII and a $1.2 \mathrm{~kb}$ fragment of $B$. subtilis DNA was isolated and ligated to HindIII-cleaved pBOE335. After transformation of the ligation mixture into MC1061, a plasmid (pBOEA335) was isolated that contained the insert oriented so that the direction of transcription of the $m c p C$ segment encoded by the $1.2 \mathrm{~kb}$ HindIII fragment was in parallel with the direction of transcription of the lac $\mathrm{Z} \alpha$ fragment of pBOE335. Strain $\mathrm{HH} 1$ was transformed with $\mathrm{pBOEA} 335$ by selection for $\mathrm{Cm}^{\mathrm{R}}$ and since the plasmid cannot replicate in B. subtilis it was integrated into the chromosome in the $\operatorname{mcp} C$ locus by homologous recombination. By using a plasmid rescue procedure similar to the one described above, DNA flanking the pBOEA335 insertion point was isolated. DNA from strain JM6 (mcpC::pBOEA335) was digested with BamHI and BglII, ligated and transformed into MC1061 by selection for $\mathrm{Ap}^{\mathrm{R}}$. A plasmid ( $\mathrm{pBOEC} 335$ ) containing $0.8 \mathrm{~kb}$ B. subtilis DNA in addition to the $1.2 \mathrm{~kb}$ HindIII fragment was isolated from one of the transformants.

Construction of an mcpC mutant. A $1 \cdot 1 \mathrm{~kb}$ EcoRV-SmaI DNA fragment containing $\mathrm{erm}$ which encodes erythromycin resistance was isolated from pHH1017 (Saxild et al., 1996) and ligated to pBOEA335 that was cleaved in the unique EcoRV site located in the $1.2 \mathrm{~kb}$ HindIII B. subtilis insert. The ligation mixture was transformed into MC1061 by selection for $\mathrm{Er}^{\mathrm{R}}$. From one of the transformants a plasmid [pBOEA(erm) 335] with the erm gene inserted was isolated. The direction of transcription of the erm gene cloned in pBOEA $(\mathrm{erm}) 335$ was the opposite of that of the $m c p C$ gene. pBOEA $($ erm $) 335$ was transformed into $\mathrm{HH} 1$ by selection for $\mathrm{Er}^{\mathrm{R}}$. The expected double-recombination event (strain JM3) was confirmed by Southern blot analysis. Strain JM3 has the erm gene inserted in the unique EcoRV site in $m c p C$.

Construction of an mcpC-lacz fusion. The $0.8 \mathrm{~kb}$ HindIII fragment containing the $m c p C$ transcription start site was isolated from $\mathrm{pCW} 10$ and ligated to $\mathrm{pDG} 268$ neo digested with HindIII. The ligation mixture was transformed into MC1061 by selection for $\mathrm{Ap}^{\mathrm{R}}$. The orientation of the insert in plasmid pHH1008 was so that the directions of transcription of $m c p C$ and $l a c Z$ were in parallel. The plasmid was linearized with $X$ hoI and transformed into $\mathrm{HH} 1$ by selection for $\mathrm{Neo}^{\mathrm{R}}$. pHH1008 was integrated into the amyE locus of HH1 by a double crossing-over event (Saxild et al., 1996), resulting in strain HH226 (amyE: :mcpC-lacZ).

\section{RESULTS \\ Nucleotide and deduced amino acid sequences of the orf1 and mcpC genes and products}

A 3135 bp nucleotide sequence of the $B$. subtilis chromosome present in plasmids $\mathrm{pCW} 10$ and pBOEC 335 was determined and is shown in Fig. 1. Nucleotides 1-396 have previously been sequenced and comprise the 3 '-end of the spl gene (Fajardo-Cavazos et al., 1993). The previously published sequence (Fajardo-Cavazos et al., 1993) lacks a $G$ residue at position 312 in the sequence shown in Fig. 1. Addition of a G residue creates a NotI restriction site. We found a NotI site that maps close to the $S p h I$ site in the $3^{\prime}$-end of the $s p l$ gene that is present in pCW10. prg-71 (the original $m c p C$ allele; Saxild $e t$ al., 1994) is located exactly between metC and pro $A B$ on the $B$. subtilis linkage map (Saxild et al., 1994) and according to previously published results (Itaya, 1993) only one NotI site has been identified in this region. We therefore suggest that the NotI site located downstream of $s p l$ is a candidate for the Not I site located at $1375 \mathrm{~kb}$ on the physical map of the B. subtilis chromosome (Itaya, 1993).

Two divergently orientated open reading frames were located downstream of $s p l$. The reading frames encode putative proteins of $226 \mathrm{aa}(30.2 \mathrm{kDa})$ and $654 \mathrm{aa}$ $(72 \cdot 1 \mathrm{kDa})$, respectively. Using the BLAST algorithm (Altschul et al., 1990), homology searches were performed to obtain information about the possible function of the two open reading frames. The homology search did not reveal information about the function of the 226 aa open reading frame (orf1). However, the 654 aa reading frame was found to be approximately $27 \%$ identical to the McpA and McpB proteins from $B$. subtilis. McpA and McpB are different MCPs involved in the chemotactic response to carbohydrates and amino acids, respectively (Hanlon \& Ordal, 1994). Based on this information and on the functional analysis presented later, we assigned the designation $m c p C$ to the 654 aa open reading frame. The $B$. subtilis genome sequencing project has not given this reading frame a systematic ' $y$ '-designation, but has instead adopted the $m c p C$ designation suggested by us. The nucleotide sequence downstream of $m c p C$ contains a potential factor-independent transcription terminator structure (Fig. 1). Further downstream of $m c p C$ the $5^{\prime}$-end of a new reading frame was located. The deduced amino acid sequence (43 aa in total) showed $40-46 \%$ identical amino acids to the $\mathrm{N}$-terminal end of 6-phosphogluconate dehydrogenase from several prokaryotic organisms. The possible function of the two reading frames lying up-and downstream of $m c p C$ was not investigated further.

A hydropathy profile (Kyte \& Doolittle, 1982) of the McpC sequence revealed two hydrophobic regions 
Table 2. Capillary assays of the wild-type and an McpC mutant strain

Values are expressed as number of bacteria in the capillary tube.

\begin{tabular}{|lcccc|}
\hline Amino acid & $\begin{array}{c}\text { Wild-type } \\
\text { (OI1085) }\end{array}$ & $\begin{array}{c}\text { McpC mutant } \\
\text { (OI3280) }\end{array}$ & $\begin{array}{c}\text { Percentage } \\
\text { reduction }\end{array}$ & $\begin{array}{c}\text { Receptor } \\
\text { class }\end{array}$ \\
\hline Cysteine & $1608 \pm 438$ & $0 \pm 44$ & 100 & A \\
Proline & $1122 \pm 206$ & $5 \pm 13$ & 99 & A \\
Threonine & $1861 \pm 684$ & $5 \pm 5$ & 99 & A \\
Glycine & $7459 \pm 1363$ & $24 \pm 36$ & 99 & A \\
Serine & $813 \pm 184$ & $7 \pm 7$ & 99 & A \\
Lysine & $1237 \pm 306$ & $18 \pm 16$ & 99 & A \\
Valine & $1028 \pm 322$ & $17 \pm 4$ & 98 & A \\
Arginine & $1061 \pm 351$ & $22 \pm 31$ & 98 & A \\
Alanine & $1452 \pm 268$ & $116 \pm 85$ & 92 & B \\
Tyrosine & $1576 \pm 289$ & $132 \pm 6$ & 92 & B \\
Glutamate & $2080 \pm 230$ & $225 \pm 96$ & 89 & B \\
Isoleucine & $4930 \pm 299$ & $621 \pm 75$ & 87 & B \\
Methionine & $1410 \pm 87$ & $295 \pm 30$ & 79 & B \\
Tryptophan & $3324 \pm 762$ & $727 \pm 67$ & 78 & B \\
Phenylalanine & $1661 \pm 656$ & $460 \pm 110$ & 72 & B \\
Leucine & $2248 \pm 293$ & $684 \pm 14$ & 70 & B \\
Aspartate & $1398 \pm 297$ & $908 \pm 126$ & 35 & B \\
Glutamine & $2437 \pm 396$ & $1602 \pm 257$ & 34 & B \\
Histidine & $1189 \pm 479$ & $873 \pm 192$ & 27 & B \\
Asparagine & $2850 \pm 89$ & $3694 \pm 308$ & 0 & C \\
\hline
\end{tabular}

characteristic of membrane-spanning segments - one segment includes amino acids 1-20 and the other amino acids 280-300 (data not shown). The location of the two membrane-spanning segments in the $\mathrm{N}$-terminal part of the $\mathrm{McpC}$ protein is very similar to the location of the hydrophobic segments found in the McpA, McpB, TlpA, TlpB and TlpC proteins (Hanlon et al., 1994; Hanlon \& Ordal, 1994). It is apparent that $\mathrm{McpC}$ is related to $\mathrm{McpB}$ and $\mathrm{McpA}$, in that there is some similarity in both the N-terminal (between the two putative membranespanning regions) and the C-terminal (following the second putative membrane-spanning region) regions, but much less than McpA and McpB have for each other (the percentage identity between $\mathrm{McpB}$ and McpA and between $\mathrm{McpB}$ and $\mathrm{McpC}$ is $60.5 \%$ and $27 \%$, respectively). Furthermore, all three MCPs are of the same size. The regions of enhanced similarity appear to be the following (numbered on the basis of the McpC sequence) : 1-29, 135-162, 243-264, 299-398, 463-536 and 590-638. The first three are thought to be in the $\mathrm{N}$ terminal region, the fourth from the beginning of the second membrane-spanning region into the C-terminal region, and the last two in the C-terminal part. Using the consensus sequence derived from the alignment of methylation sites of several methylated proteins constructed by Le Moual \& Koshland (1996), we located potential methylation sites at amino acid positions 364 , 385,616 and 623 in the McpC sequence. The potential methylation sites at positions 364 and 623 in McpC are located at similar positions in McpA and McpB (Hanlon
\& Ordal, 1994), whereas the other two are located at different positions.

\section{Characterization of a mutant defective in mcpC}

To test the function of the $\mathrm{McpC}$ protein, the $m c p C$ gene was disrupted by insertion of an erythromycin antibiotic resistance DNA cassette (erm gene) as described in Methods. Since the deduced amino acid sequence of McpC shows similarity to the McpA and McpB sequences, strain OI3280 (mcpC::erm) was tested in a capillary assay for its chemotactic response to all 20 amino acids. As shown in Table 2, the taxis to all amino acids except for asparagine (receptor class $\mathrm{C}$ in Table 2) was more or less reduced in strain OI3280 when compared to the wild-type strain. An almost total loss of taxis to cysteine, proline, glycine, serine, lysine, valine and arginine was observed (receptor class A in Table 2) while the response to the remaining 11 amino acids was reduced to $80-20 \%$ of the levels found in the wild-type (receptor class B in Table 2). In previous experiments, we found that $m c p B$ mutants are completely defective in asparagine taxis and partially defective in glutamine, aspartate and histidine taxis (Hanlon \& Ordal, 1994). To confirm that glutamine, aspartate, histidine and possibly also glutamate taxes are mediated by $\mathrm{McpB}$ and $\mathrm{McpC}$, we constructed a double mutant and carried out capillary assays. There was no taxis to any of these amino acids, as expected (data not shown). The double 


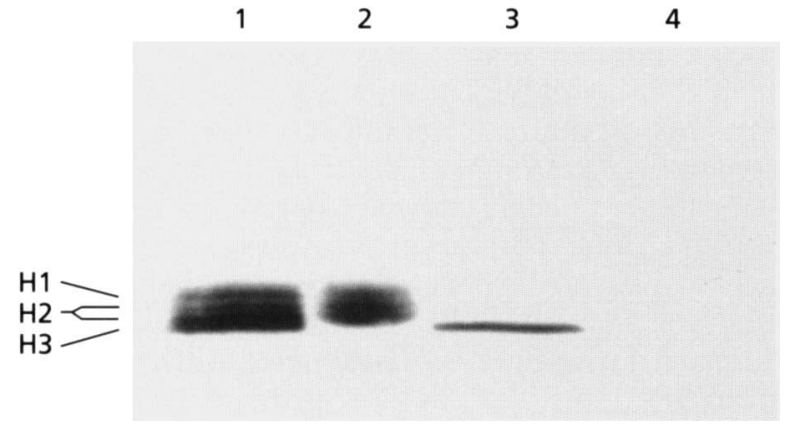

Fig. 2. In vivo protein methylation. Cells were labelled with [methyl- ${ }^{3} \mathrm{H}$ ]methionine for $15 \mathrm{~min}$ and methylated membrane proteins were separated by SDS-PAGE and visualized by fluorography as described in Methods. Lanes: 1, wild-type strain Ol1085; 2 , mcpC mutant strain OI3280; 3, deletion strain Ol3202 (mcpA mcpB t/pA t/pB t/pC); 4, strain OI3281, which is an mcpC mutant derivative of strain 013202 .

mutant was also tested in capillary assays for taxis to five other class B amino acids (tryptophan, methionine, isoleucine, phenylalanine and leucine) and levels identical to the ones found for the McpC mutant (Table 2) were observed (data not shown).

The wild-type strain OI1085 and different deletion mutant derivatives were labelled with $\left[\right.$ methyl $\left.-^{3} \mathrm{H}\right]$ methionine and analysed for their content of methylated membrane proteins as described in the Methods section. Four radiolabelled protein bands were visible in the 76-97 kDa region of the methylation gel (Fig. 2). The upper band was designated $\mathrm{H} 1$ and has previously been shown to be the protein encoded by $m c p A$. The two middle bands were designated $\mathrm{H} 2$ and are possibly TlpA and TlpB since they are missing in a strain deleted for $m c p A, m c p B$, $t l p A$ and $t l p B$ (Fig. 2). Strains OI 3280 (mcpC::erm) and OI3281 (lacking all known MCPs) lack the lower part of the lowest band, designated $\mathrm{H} 3$ (Fig. 2) (the upper part of which is McpB; Hanlon \& Ordal, 1994). This observation strongly indicates that $m c p C$ encodes a methylated membrane protein corresponding to part of the $\mathrm{H} 3$ band.

\section{Mapping of the $m c p C$ transcription start site}

Two oligonucleotides which are complementary to nucleotides 933-948 (primer 1) and 1006-1024 (primer 2 ) in the $m c p C$ sequence (Fig. 1) were used in two primer extension reactions containing RNA isolated from $\mathrm{HH} 1$ cells harvested in the late-exponential growth phase. As illustrated in Fig. 3, primer 2 was extended to a T residue which is complementary to the $A$ residue no. $892\left(\mathrm{~A}_{\mathbf{8 9 2}}\right)$ in the $m c p C$ sequence. The same result was obtained with primer 1 (data not shown). Immediately upstream of the $A_{892}$ position we located a sequence that resembles the recognition sequence for the $\sigma^{D}$ form of RNA polymerase (857-TTCAT-16 ${ }_{n t}$-CCGATAT-884; Gilman et al., 1981).

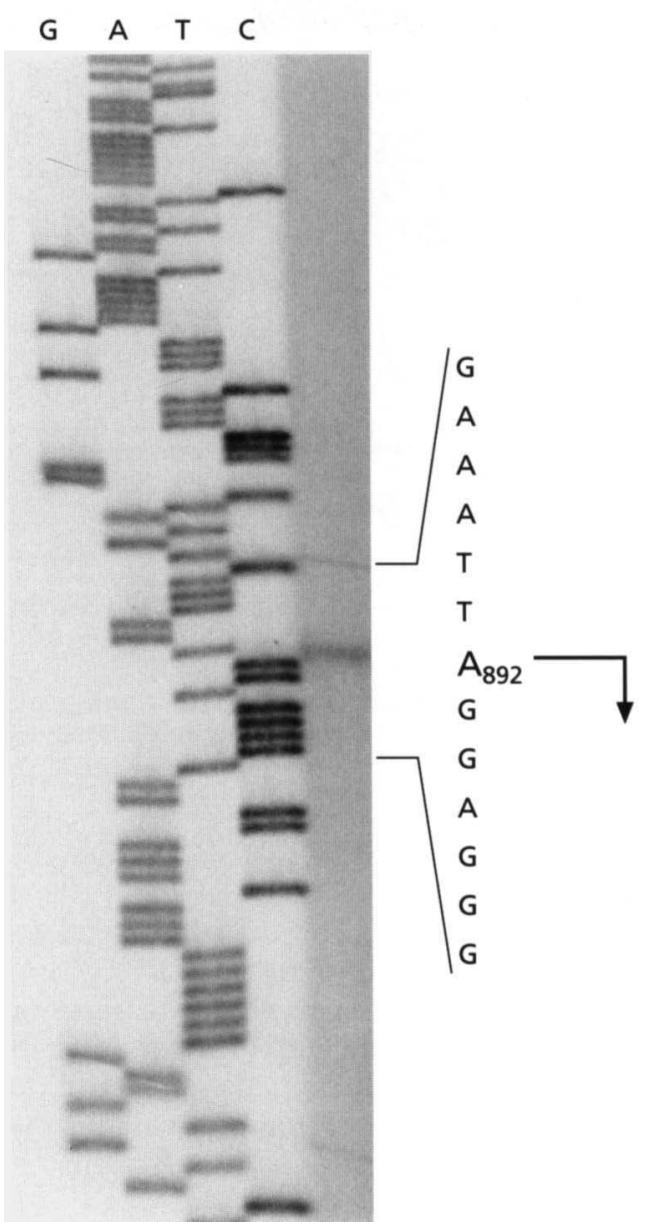

Fig. 3. Mapping of the $m c p C$ transcription start point by primer extension analysis. Total RNA was isolated from strain $\mathrm{HH} 1$ harvested in the late-exponential growth phase. First-strand cDNA synthesis was performed as described in Methods. The DNA primer (primer 2) is complementary to nucleotides 1024-1006 (Fig. 1). The most likely transcription start point $\left(A_{892}\right)$ is indicated by a bent arrow. The emphasized sequence is given as the complementary sequence of the one shown in the sequencing ladder.

\section{Expression of $\mathbf{m c p C}$}

Strains HH226 (amyE:: mcpC-lacZ) and MJ10 (amyE: : $m c p C-l a c Z$ sigD::cat) were grown in minimal medium and the level of $\beta$-galactosidase was determined. The $m c p C$ expression started to increase in the late-exponential growth phase and reached a maximum during the early-stationary phase (Fig. 4). An identical regulatory pattern was observed when strain $\mathrm{HH} 226$ was grown in rich medium (data not shown). No $\beta$-galactosidase activity could be detected in the sig $D$ genetic background and this strongly indicated that $m c p C$ expression is dependent on the sigD-encoded sigma factor (Fig. 4). The influence of growth on different carbon sources on the expression of $m c p C$ was analysed in $\mathrm{HH} 226$ cells grown on glucose, glycerol or succinate. No significant 


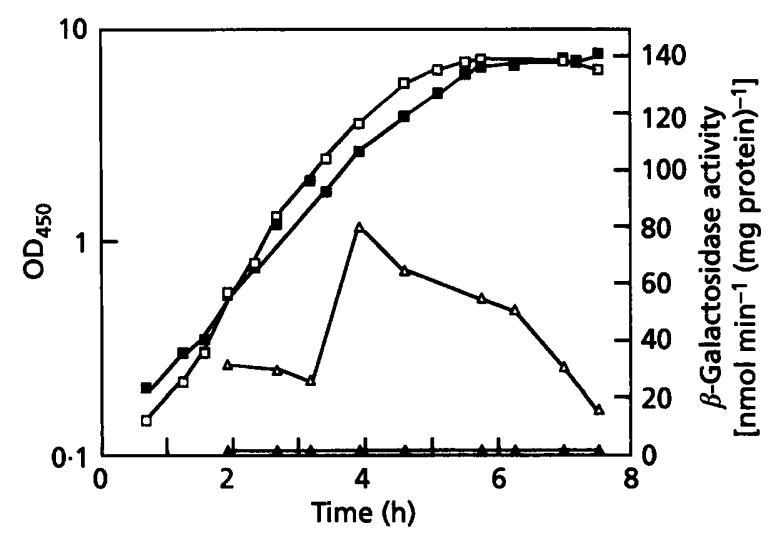

Fig. 4. Effect of the growth phase on the expression of an mcpC-lacZ fusion. $\square, \square, O_{450} ; \triangle, \Delta, \beta$-galactosidase activity. Open symbols, data from strain $\mathrm{HH} 226$ (mcpC-lacZ); filled symbols, data from strain JM10 (mcpC-lacZ sigD). $\beta$-Galactosidase activity was measured as described in Methods.

changes in the expression level or in the growth-phasedependent variation were observed (data not shown). Different mutations were introduced into strain HH226 to characterize the stationary phase signal that is responsible for the increase in $m c p C$ expression. Mutations in the transition state regulator gene $a b r B$ or in the sporulation initiation control gene spoOA did not affect the $m c p C$ expression (data not shown). Furthermore, purine and pyrimidine starvation of purine and pyrimidine auxotrophic derivatives of strain $\mathrm{HH} 226$, respectively, resulted in an increase in $m c p C$ expression that was identical to the one observed when the wildtype strain enters the stationary phase as illustrated in Fig. 4 (data not shown). Therefore, we conclude that under the conditions tested we have not been able to identify a specific genetic factor or physiological signal that is responsible for the induction of $m c p C$ expression.

\section{DISCUSSION}

In this report, we describe a novel gene, $m c p C$, that is involved in the chemotactic behaviour of $B$. subtilis. Zuberi et al. (1990) have previously screened the $B$. subtilis chromosome for genes involved in chemotaxis and motility and it was suggested that at least two transcription units (cheX and a mot locus) were located near $p t s I$. In addition, Fredrick \& Helmann (1994) have located $c h e V$ in the same region. $m c p C$ is also placed close to $p t s I$ ( $p t s I$ is located immediately upstream of $s p l)$, but neither the phenotype of an $m c p C$ mutant nor the nucleotide sequence of the $m c p C$ gene corresponded to the data reported for the chemotaxis and motility loci previously assigned to this part of the chromosome. This indicates that the region immediately downstream of $s p l$ contains at least four genes involved in chemotaxis and motility, namely $m c p C$, cheX, cheV and a mot gene.

It is clear that $\mathrm{McpC}$ plays a major role in chemotaxis in $B$. subtilis. It is required for taxis to the amino acids cysteine, proline, threonine, glycine, serine, lysine, valine and arginine and for some others - aspartate, glutamine, histidine and glutamate $-\mathrm{McpC}$ and $\mathrm{McpB}$ are the two receptors either of which can mediate the taxis. Since an $m c p C m c p B$ double mutant has not lost taxis to tryptophan, methionine, isoleucine, phenylalanine and leucine, other uncharacterized MCPs must be present in $B$. subtilis. As hypothesized previously, taxis to amino acids in B. subtilis is probably not mediated by binding of the amino acid to the receptor directly, like serine binding to Tsr in E. coli (Hedblom \& Adler, 1980), but instead an amino acid/binding-protein complex probably binds the receptor, as for maltose taxis in E. coli (Kossmann et al., 1988). The great structural variety in the amino acids whose taxes are mediated through $\mathrm{McpC}$ is further testimony in support of this hypothesis.

There are selected places in both the N-terminal and Cterminal regions where $\mathrm{McpC}$ is more similar to $\mathrm{McpB}$ and McpA. There is reason to believe that there is a family of binding proteins that mediates the taxis to the respective amino acids. This supposition is supported by the fact that both McpB and McpC each can mediate taxis to aspartate, histidine and glutamine. In the $\mathrm{N}$ terminal part, we imagine the regions of conserved amino acids are where the binding proteins come into contact with the respective MCPs. In the C-terminal part, we imagine conserved regions are where the proteins that mediate the excitatory and adaptational reactions - CheA, CheW, CheV, CheR, CheB, CheC and $\mathrm{CheD}$ - come into contact with the receptor. This type of information should eventually prove useful in investigating how each of the chemotaxis proteins come into contact with the receptors.

Based on nucleotide sequence data it has been suggested that $m c p A, m c p B, t l p A, t l p B$ and $t l p C$ are all expressed from promoters recognized by the $\sigma^{D}$ form of RNA polymerase (Hanlon et al., 1994; Hanlon \& Ordal, 1994). In this report, we show experimentally that $m c p C$ expression is dependent on the sigD gene product. The transcription start site was located only 14 nucleotides upstream of the initiation codon. This is a surprisingly short leader sequence. The level of expression of $m c p C$ was increased in the late-exponential growth phase and was maximal in the early-stationary phase. The same growth-phase-dependent pattern has been reported for the cellular level of SigD (Ordal et al., 1993). Based on the fact that the control of expression of sigD and $m c p C$ is independent of global regulators such as AbrB and SpoA (Márquez-Magana et al., 1994), we suggest that $m c p C$ expression may be strictly correlated with the level of SigD. The original reported $m c p C$ allele ( $p r g-$ $71::$ lac $Z$ ) showed an increase in expression when cells entered the stationary phase as a consequence of purine starvation (Saxild et al., 1994). From the data presented here, we conclude that growth arrest in general and not a specific purine starvation signal is responsible for the induction of $m c p C$ expression.

\section{ACKNOWLEDGEMENTS}

We thank C. Wethje for the isolation and construction of plasmids pCW 1 and pCW 10 and Kirsten Hansen for excellent 
technical assistance. This research received financial support from the Saxild Family Foundation and was supported by EU contract BIO2-CT95-0278.

\section{REFERENCES}

Altschul, S. F., Gish, W., Miller, W., Myers, E. W. \& Lipman, D. J. (1990). Basic local alignment search tool. J Mol Biol 215, 403-410.

Birnboim, H. C. \& Doly, J. (1979). A rapid alkaline extraction procedure for screening recombinant plasmid DNA. Nucleic Acids Res 7, 1513-1523.

Bischoff, D. S. \& Ordal, G. W. (1991). Sequence and characterization of Bacillus subtilis $\mathrm{CheB}$, a homolog of Escherichia coli $\mathrm{CheY}$, and its role in different mechanism of chemotaxis. $\mathrm{J} \mathrm{Biol}$ Chem 266, 12301-12305.

Boylan, R. J., Mendelson, N. H., Brooks, D. \& Young, F. E. (1972). Regulation of the bacterial cell wall: analysis of a mutant of Bacillus subtilis defective in biosynthesis of teichoic acid. J Bacteriol 110, 281-290.

Errington, J. (1986). A general method for fusion of the Escherichia coli lacZ gene to chromosomal genes in Bacillus subtilis. J Gen Microbiol 132, 2953-2966.

Fajardo-Cavazos, P., Salazar, C. \& Nicholson, W. L. (1993). Molecular cloning and characterization of the Bacillus subtilis spore photoproduct lyase $(s p l)$ gene, which is involved in repair of UV radiation-induced DNA damage during spore germination. $J$ Bacteriol 175, 1735-1744.

Fredrick, K. L. \& Helmann, J. D. (1994). Dual chemotaxis signaling pathways in Bacillus subtilis: a $\sigma^{\mathrm{D}}$-dependent gene encodes a novel protein with both $\mathrm{CheW}$ and CheY homologous domains. $J$ Bacteriol 176, 2727-2735.

Fuhrer, D. K. \& Ordal, G. W. (1991). Bacillus subtilis CheN, a homolog of CheA, the central regulator of chemotaxis in Escherichia coli. J Bacteriol 173, 7443-7448.

Gilman, M. Z., Wings, J. L. \& Chamberlin, M. J. (1981). Nucleotide sequence of two Bacillus subtilis promoters used by Bacillus subtilis sigma-28 RNA polymerase. Nucleic Acids Res 9, 59916000.

Hanahan, D. (1983). Studies on transformation of Escherichia coli with plasmids. $J \mathrm{Mol}$ Biol 166, 557-580.

Hanlon, D. W. \& Ordal, G. W. (1994). Cloning and characterization of genes encoding methyl-accepting chemotaxis proteins in Bacillus subtilis. J Biol Chem 269, 14038-14046.

Hanlon, D. W., Márquez-Magana, L. M., Carpenter, P. B., Chamberlin, M. J. \& Ordal, G. W. (1992). Sequence and characterization of Bacillus subtilis CheW. J Biol Chem 267, 12055-12060.

Hanlon, D. W., Rosario, M. M. L., Ordal, G. W., Venema, G. \& van Sinderen, D. (1994). Identification of TlpC, a novel $62 \mathrm{kDa} M C P-$ like protein from Bacillus subtilis. Microbiology 140, 1847-1854.

Hedblom, M. L. \& Adler, J. (1980). Genetic and biochemical properties of Escherichia coli mutants with defects in serine chemotaxis. J Bacteriol 144, 1048-1060.

Itaya, M. (1993). Physical map of the Bacillus subtilis 168 chromosome. In Bacillus subtilis and Other Gram-Positive Bacteria: Biochemistry, Physiology, and Molecular Genetics, pp. 463-471. Edited by A. L. Sonenshein, J. A. Hoch \& R. Losick. Washington, DC: American Society for Microbiology.

Kirsch, M. L., Peters, P. D., Hanlon, D. W., Kirby, J. R. \& Ordal, G. W. (1993a). Chemotactic methylesterase promotes adaptation to high concentrations of attractant in Bacillus subtilis. J Biol Chem 268, 18610-18616.
Kirsch, M. L., Zuberi, A. R., Henner, D., Peters, P. D., Yazdi, M. A. \& Ordal, G. W. (1993b). Chemotactic methyltransferase promotes adaptation to repellents in Bacillus subtilis. J Biol Chem 268, 25350-25356.

Kossmann, M., Wolff, C. \& Manson, M. D. (1988). Maltose chemoreceptor of Escherichia coli : interaction of maltose-binding protein and the Tar signal transducer. J Bacteriol 170, 4516-4521.

Kyte, J. \& Doolittle, R. F. (1982). A simple method for displaying the hydropathic character of a protein. J Mol Biol 157, 105-132. Laemmli, U. K. (1970). Cleavage of structural proteins during the assembly of the head of bacteriophage T4. Nature 227, 680-685.

Laskey, R. A. \& Mills, A. D. (1975). Quantitative film detection of ${ }^{3} \mathrm{H}$ and ${ }^{14} \mathrm{C}$ in polyacrylamide gels by fluorography. Eur J Biochem 56, 335-341.

Le Moual, H. \& Koshland, D. E., Jr (1996). Molecular evolution of the C-terminal cytoplasmic domain of a superfamily of bacterial receptors involved in taxis. $J \mathrm{Mol}$ Biol 261, 568-585.

Márquez-Magana, L. M., Mirel, D. B. \& Chamberlin, M. J. (1994). Regulation of $\sigma^{D}$ expression and activity by $s p o 0, a b r B$, and $\sin$ gene products in Bacillus subtilis. J Bacteriol 176, 2435-2438.

Miller, J. H. (1972). Assay of $\beta$-galactosidase. In Experiments in Molecular Genetics, pp. 352-355. Cold Spring Harbor, NY: Cold Spring Harbor Laboratory.

Ordal, G. W. \& Goldman, D. J. (1975). Chemotaxis away from uncouplers of oxidative phosphorylation in Bacillus subtilis. Science 189, 802-804.

Ordal, G. W., Villani, D. P. \& Gibson, K. J. (1977). Amino acid chemoreceptors of Bacillus subtilis. J Bacteriol 129, 156-165.

Ordal, G. W., Márquez-Magana, L. \& Chamberlin, M. J. (1993). Motility and chemotaxis. In Bacillus subtilis and Other GramPositive Bacteria, pp. 765-784. Edited by A. L. Sonenshein, J. A. Hoch \& R. Losick. Washington, DC: American Society for Microbiology.

Rosario, M. M., Fredrick, K. L., Ordal, G. W. \& Helmann, J. D. (1994). Chemotaxis in Bacillus subtilis requires either of two functionally redundant $\mathrm{CheW}$ homologs. J Bacteriol 176, 27362739.

Rosario, M. M. L. \& Ordal, G. W. (1996). CheC and CheD interact to regulate methylation of Bacillus subtilis methyl-accepting chemotaxis proteins. Mol Microbiol 21, 511-518.

Sanger, F., Nicklen, S. \& Coulson, A. R. (1977). DNA sequencing with chain terminating inhibitors. Proc Natl Acad Sci USA 74, 5463-5467.

Saxild, H. H. \& Nygaard, P. (1987). Genetic and physiological characterization of Bacillus subtilis mutants resistant to purine analogs. J Bacteriol 169, 2977-2983.

Saxild, H. H., Jensen, C. L., Hubrechts, P. \& Hammer, K. (1994). Isolation and characterization of Bacillus subtilis genomic lacZ fusions induced during partial purine starvation. J Bacteriol 176, 276-283.

Saxild, H. H., Jacobsen, J. H. \& Nygaard, P. (1995). Functional analysis of the Bacillus subtilis purT gene encoding formatedependent glycinamide ribonucleotide transformylase. Microbiology 141, 2211-2218.

Saxild, H. H., Andersen, L. N. \& Hammer, K. (1996). dra-nupC$p d p$ operon of Bacillus subtilis : nucleotide sequence, induction by deoxyribonucleosides, and transcriptional regulation by the deoR-encoded DeoR repressor protein. J Bacteriol 178, 424-434.

Ullah, A. H. \& Ordal, G. W. (1981). In vivo and in vitro chemotactic methylation in Bacillus subtilis. J Bacteriol 145, 958-965.

Youngman, P., Perkins, J. B. \& Losick, R. (1984). A novel method 
for the rapid cloning in Escherichia coli of Bacillus subtilis chromosomal DNA adjacent to Tn917 insertions. Mol Gen Genet 195, 424-433.

Zuberi, A. R., Ying, C., Parker, H. M. \& Ordal, G. W. (1990). Transposon Tn917lacZ mutagenesis of Bacillus subtilis: identifi- cation of two new loci required for motility and chemotaxis. $J$ Bacteriol 172, 6841-6848.

Received 12 May 1997; revised 13 June 1997; accepted 16 June 1997. 